\title{
Lateral
}

Journal of the Cultural Studies Association

\section{Review of Bans, Walls, Raids, Sanctuary: Understanding U.S. Immigration for the Twenty-First Century by A. Naomi Paik (University of California Press)}

\author{
by Travis Franks | Book Reviews, Issue 10.1 (Spring 2021)
}

\begin{abstract}
A. Naomi Paik's Bans, Walls, Raids, Sanctuary responds to a trio of executive orders on immigration policy issued in the early days of Donald Trump's presidency. Those orders sought to make good on campaign promises to further restrict immigration by banning citizens from Muslim-majority countries, allocating funds to expand a border wall between the US and Mexico, and ramping up home and workplace deportation raids by Immigration and Customs Enforcement (ICE). Paik delineates how these legal barriers came to be by locating them in relation to the nation's formative immigration policies, backlash to the liberation movements of the 1960s and 1970s, and the global repercussions of neoliberalism. Highlighting the work of Indigenous activists, Paik eventually calls not only for the dramatic restructuring of the nation's immigration system but also for the creation of a more just society based on relationships that reject the politics of inclusion and exclusion.
\end{abstract}

KEYWORDS border, Donald Trump, immigration, Muslims, wall, xenophobia

Bans, Walls, Raids, Sanctuary: Understanding U.S. Immigration for the TwentyFirst Century. By A. Naomi Paik. Oakland: University of California Press, 2020, 173 pp. (paperback). ISBN 978-0-520-30512-0. US List: \$18.95.

A. Naomi Paik's Bans, Walls, Raids, Sanctuary responds to a trio of executive orders on immigration policy issued in the early days of Donald Trump's presidency. Those orders sought to make good on campaign promises to further restrict immigration by banning citizens from Muslim-majority countries, allocating funds to expand a border wall between the United States and Mexico, and ramping up home and workplace deportation raids by Immigration and Customs Enforcement (ICE). Paik delineates how these legal barriers came to be by locating them in relation to the nation's formative immigration policies, backlash to the liberation movements of the 1960s and 1970s, and the global repercussions of neoliberalism. Highlighting the work of Indigenous activists like Nick Estes and Melanie Yazzie, Paik eventually calls not only for the dramatic restructuring of the nation's immigration system but also for the creation of a more just society based on relationships that reject the us-versus-them politics of inclusion and exclusion.

Bans, Walls, Raids, Sanctuary is Paik's second book and the twelfth installment in University of California Press's American Studies Now series, edited by Lisa Duggan and 
Curtis Marez. The series consists of concise works meant to address urgent current events and foster discussions amongst students and activists alike. In addition to the standard table of contents, the front matter includes chapter overviews with pithy summaries and pertinent keywords, as well as a prefatory note titled "How to Use This Book." There, Paik suggests that the text functions as a form of resistance to the Trump administration and as a broader critique of the current so-called immigration crisis in the US. She frames her critique as a history of the present, placing Trump's recent nativist policies within the longue durée of exclusionary practices in the US and forecasting ways in which other seemingly less vulnerable groups may soon be targeted.

Of significant note, Paik frames her critique of exclusionary immigration laws in the US in relation to the nation's settler colonial origins. Paik's previous work on citizenship and the carceral state shows here, as she routinely refers to Kelly Lytle Hernández's City of Inmates: Conquest, Rebellion, and the Rise of Human Caging in Los Angeles, 1771-1965 (2017) when discussing settler colonialism rather than turning to the ubiquitous works of Patrick Wolfe or Lorenzo Veracini. As such, Paik avoids a too-broad settler-Indigenous binary and theoretical generalizing about settler colonialism in toto. Indeed, she deftly weaves an examination of specific legal histories of Indigenous and Black peoples into her analysis of the various "others" upon whom US settler society has relied, particularly Chinese, Arab, Muslim, and Latinx populations, arguing that the legal understanding of immigration as a matter of national sovereignty "reveals the centrality of settler colonialism and slavery-and in turn Native elimination and anti-Black racism-to our deportation obsession today" (79). In this way, Bans, Walls, Raids, and Sanctuary aligns with other recent works emphasizing relational analysis, such as Lisa Lowe's The Intimacy of Four Continents and the anthology Relational Formations of Race, edited by Natalia Molina, Daniel Martinez HoSang, and Ramón A. Gutiérrez.

The book consists of an introduction, four body chapters, and an epilogue. Those body chapters individually address the four concepts of the book's title: bans, walls, raids, and sanctuary. In each of these, Paik unpacks the legal histories leading to Trump's 2017 executive orders concerning immigration.

In Chapter 2, Paik focuses her analysis on bans by placing Trump's Muslim-majority travel restrictions in conversation with the dispossession of Indigenous peoples, raciallycoded naturalization laws, nineteenth-century Chinese exclusion acts, and post-war immigration quotas, arguing that the colonial origins of the US are made possible by white nationalist ideals and form the concept of a white nation that persist today. She also demonstrates the capricious nature of contemporary anti-Muslim racism, which amalgamates "those who appear Middle Eastern, Arab, or Muslim" into an emerging racial category marked as always already potential terrorists (31).

In Chapter 3, "Walls," Paik links Trump's executive order to build a wall along the US southern border to legislative acts such as the 1924 Johnson-Reed Act and the 1929 Undesirable Aliens Act, which transformed border crossing into an issue of national security and policing rather than one of labor rights. Paik also clearly demonstrates how the rise of neoliberal policies such as NAFTA coincided with the increased criminalization of migrants from Mexico and Central and South America and the booming prison industry.

In Chapter 4, "Raids," Paik parallels current deportation practices with previous removal 
legislation, namely the 1830 Indian Removal Act and the 1850 Fugitive Slave Act. That is, these historical legislative acts represent a precedent for the forced removal of noncitizens by the state, and just as the originary acts are based on anti-Indigenous and anti-Black racism, so too is Trump's executive order based on nativist fears of foreigners. Further, Paik insists that deportation has come to be seen as a "common sense" form of enforcing the boundaries between those who are included or excluded, paying particular attention to the role that Democrat administrations under former presidents Clinton and Obama played in the criminalization of noncitizens (95-96).

The final body chapter, "Sanctuary," charts a history of the extralegal concept of sanctuary in relation to state sovereignty. Paik also develops here her concept of abolitionist sanctuary, a holistic approach to reform that extends beyond "single issueslike creating a path to citizenship for some at the cost of criminalizing everyone else," and seeks to eradicate "root causes that have led to the predicaments of bans, walls, and raids" (113). In the epilogue, Paik gestures toward articulations of Indigenous sovereignty that predate the US as a way of imagining alternative forms of belonging that can shape the future.

Given the text's brevity and Paik's clear, engaging prose, Bans, Walls, Raids, and Sanctuary will make an excellent addition to introductory courses focusing on migration, legal history, critical race, or US empire. Because it is also so timely, the book has the potential to find a wider readership beyond university classrooms and will likely appeal to anyone interested in challenging attacks on minoritized groups. Indeed, Bans, Walls, Raids, and Sanctuary could easily share shelf space with the works of Rebecca Solnit and Naomi Klein because of Paik's ability to combine academic rigor and a convincing sense of urgency into a story that we need to hear and act on here and now.

\title{
Author Information
}

\author{
Travis Franks \\ Travis Franks is a postdoctoral fellow in the Kilachand Honors College at \\ Boston University. A McNair and Fulbright alum, his writing appears in \\ MELUS, AIQ, and Western American Literature, and he is currently at work on \\ a book project titled Settler Nativism: Indigeneity and Diaspora in \\ Contemporary Narratives of Belonging. \\ View all of Travis Franks's articles.
}

\section{Article details}

Travis Franks, "Review of Bans, Walls, Raids, Sanctuary: Understanding U.S. Immigration for the Twenty-First Century by A. Naomi Paik (University of California Press)," Lateral 10.1 (2021). 
https://doi.org/10.25158/L10.1.25

This content is licensed under a Creative Commons Attribution-NonCommercial 4.0 International License. Copyright is retained by authors.

Lateral is the peer-reviewed, open access journal of the Cultural Studies Association.

ISSN 2469-4053 